\title{
A PERSPECTIVE ON MERGER REVIEW AND OTHER CURRENT TOPICS UNDER THE COMPETITION ACT
}

\author{
CALVIN S. GOLDMAN, Q.C.*
}

In this article, the author examines recent developments under the federal Competition Act and its potential impact on mergers in the oil and gas industry. The author provides a broad overview of the merger review process and highlights recent Canadian case law on mergers. Implications of the Canada-U.S. Free Trade Agreement on the administration of competition law in Canada are also canvassed.

TABLE OF CONTENTS

I. INTRODUCTION

II. THE MERGER REVIEW PROCESS 172

A. LEGISLATIVE PROVISIONS 172

B. OTHER AMENDMENTS 175

C. THE APPROACH TAKEN TO MERGER RESOLUTION 176

D. OTHER CASE EXAMPLES - RESOURCE INDUSTRIES 178

III. RECENT DEVELOPMENTS 180

A. THE CHRYSLER CANADA CASE 180

B. THE IMPERIAL OIL/TEXACO CANADA MERGER 181

C. THE THOMSON NEWSPAPERS CASE 183

D. THE COUTURE CASE 184

E. THE STEINBERG'S CASE

F. THE DIRECTOR'S PRIORITIES 185

G. PRE-MERGER NEGOTIATIONS 186

IV. IMPLICATIONS OF THE FREE TRADE AGREEMENT 187

V. CONCLUSION 190

\section{INTRODUCTION}

I hope that my remarks today prove to be of interest to you in the course of your examination of current legal topics related to the oil and gas industry in Canada. The developments under the Competition $A c t^{\prime}$ over the past few years have certainly included matters with immediate bearing on the oil and gas industry. I understand that your Foundation's program covers many topical issues that may affect this industry; therefore I will try to present a broad overview of the merger review process and other current topics designed to update the practitioner on these areas of the Competition Act. Although this paper is not limited to the oil and gas industry, the procedural and substantive matters addressed ought to be applicable to considerations by lawyers advising businesses in this industry.

The oil and gas industry has certainly faced a period of transition since it was deregulated as a result of the $\mathbf{1 9 8 5}$ Western Accord. International market forces by

* Partner, Davies, Ward \& Beck, Toronto, Canada. From May 1986 until October 1989, Mr. Goldman was the Director of Investigation and Research, Bureau of Competition Policy, Ottawa.

1. S.C. 1986, c. 26 [hereinafter Competition Act]. 
and large have brought about a substantial decline in oil prices, and natural gas processing capacity has also been surplus to market requirements. A number of major transactions have taken place in recent years giving new corporate entities a different position in the industry. Even in recent months, news headlines have referred to such topics as the changes taking place in relation to heavy oil projects or to the future of Petro-Canada or to the volume of oil and gas assets available for sale in Western Canada. Corporate profits, even for some large integrated oil companies, have seen considerably better years than the recent period. All of this reflects an industry that will continue to face major challenges and changes in order to stay competitive on a national and international basis.

Careful planning is necessitated when the bottom line has comparatively less flexibility than it used to have. As part of the planning process, Competition Act issues may have to be considered, particularly when corporations are increasingly examining ways to specialize in core business areas. Achieving certain scale economies often necessitates consideration of the merger provisions of the Act, especially in relation to the acquisition of a competitor in the market. In this regard, all one has to do is examine the listing of merger examinations in the Annual Reports to Parliament of the Director of Investigation and Research to see the sizeable amount of transactions in this industry that have been the subject of review, or at least notification, under the Competition Act. There is every reason to believe that the degree of contact between the industry and the Bureau of Competition Policy will continue to be significant in the immediate future as the industry undergoes further changes.

At the outset of my remarks, I intend to provide an introductory perspective on the merger review process with some case examples that bear on this industry. In the course of those remarks, I will also briefly touch upon some of the other amendments that were included in the 1986 legislation. I then propose to highlight a number of recent developments which should be of topical interest to those who do not spend most of their time practising in this field. Finally, I will discuss some of the implications of the Canada-U.S. Free Trade Agreement on the administration of competition law in Canada.

\section{THE MERGER REVIEW PROCESS}

\section{A. LEGISLATIVE PROVISIONS}

In the Competition Act which was passed in June 1986, the legislators set out to write a law that would effectively discourage and prevent practices which harm competition. But they also recognized the need to do so without placing crippling restraints on Canadian industry in relation to foreign competition. A fundamental sense of balance was designed in the legislation so that it could be administered in an effective and realistic manner. This sense of balance is found in a number of key parts of the legislation.

For example, the purpose clause in section 1.1 states that the legislation's mandate is to maintain and encourage competition in Canada in order to promote the efficiency and adaptability of the Canadian economy. A specific objective in that mandate is "to expand opportunities for Canadian participation in world markets, while at the same time recognizing the role of foreign competition in Canada". An additional objective is "to provide consumers with competitive prices and product choices". Finding the equilibrium among these objectives is often not an easy task, to say the least. It was, 
however, one of the primary objectives we sought to attain in the Bureau of Competition Policy in implementing the new legislation in order to enable the legislation to be administered effectively and realistically.

With the passage of the Competition Act, the merger review provisions in the Act were completely overhauled. Under the predecessor legislation, the Combines Investigation Act, ${ }^{2}$ mergers and monopoly were addressed in the context of criminal law. There were serious practical problems with that approach. The statutory test and the burden of proof required for conviction under criminal law standards were so onerous that the government prosecutor's role was a nearly impossible task. Public detriment beyond a reasonable doubt had to be proved. In the 76 years prior to the passage of the Competition Act, there was just one conviction for monopoly. Nine merger cases had been brought before the courts during that time. None were successfully contested.

The Competition Act provides that mergers and the newly enacted abuse of dominant position provisions (which replaced the monopoly section) are now matters of administrative law that are adjudicated, not by the courts, but by a quasi-judicial body known as the Competition Tribunal. This does not involve the criminal process or the criminal burden of proof. The legislative test is now whether the merger or proposed merger prevents or lessens competition substantially or is likely to do so. A similar test of substantially lessening competition is incorporated in the elements of the new abuse of dominance provisions.

The legislation provides that in the administration of the merger review provisions both sides of the balance sheet are to be considered. For example, in assessing the impact of a merger on competition, the legislation stipulates that the analysis must go beyond calculating only market share or concentration ratios. Other elements may be considered, such as actual or likely foreign competition and the presence or absence of tariff or non-tariff barriers to international trade. The merger law also provides that consideration be given not only to the negative effects on competition but also to the gains in efficiency resulting from the merger, with particular weight given to those gains that will produce a net trade benefit for the economy as discussed below.

The balancing of these considerations is also relevant to another new set of provisions in the 1986 legislation which provides an alternative to embarking on a merger - the provisions relating to specialization agreements. Specialization agreements are particularly important to Canada, whose manufacturing sector contains a large number of small-scale plants. They may eventually prove to be a significant vehicle for businesses that are adapting to wider markets under GATT or Canada-U.S. Free Trade. Under the new Act, two companies that want to specialize in the production of an article or service can apply to the Competition Tribunal for prior registration. If the Tribunal finds that the agreement will likely produce gains in efficiency that outweigh the negative effects on competition, the Tribunal may approve the agreement.

While the substantive language of the Canadian and American merger laws is similar, there are important statutory differences. As mentioned above, the Canadian legislation contains a non-exhaustive list of factors to be considered in assessing a merger. Seven factors are referred to expressly in the statutory list. These are:

- the extent of existing or likely effective foreign competition; 
[VOL. XXIX, NO. 1

- the possibility of a failing business;

- the availability of acceptable product substitution;

- the existence of any trade, regulatory or other barriers to entry;

- the extent of effective competition remaining in a market;

- the removal of a vigorous and effective competitor; and

- the nature and extent of innovation.

As well, any other factors relevant to competition in a market may be considered; for example, the extent to which purchasers have countervailing purchasing power may be relevant in some cases. These factors, which have been drafted in neutral terms, do not unequivocally establish whether competition would increase or decrease as a result of a merger. They each form an important element in the balancing process essential to effective merger analysis. They ensure that the analysis is one that is not based solely on quantitative criteria such as market share or concentration ratios.

Another difference from American antitrust law is that the Canadian merger law specifically provides that the Tribunal shall not prohibit a merger or proposed merger if the parties satisfy the Tribunal that the merger has brought about or is likely to bring about gains in efficiency that will be greater than, and will offset, the effects of any prevention or lessening of competition resulting from the merger, and that such efficiency gains would not likely be attained if a prohibition order were made. In recognition of the importance of foreign trade to the Canadian economy, the Act also explicitly directs consideration of whether such efficiency gains would result in a significant increase in the real value of exports or in significant substitution of domestic product for imports. In the United States, efficiency considerations are done as part of administrative practice under administrative guidelines; they are not specifically codified in the governing statute as they are in Canada.

A true efficiency gain is one that involves a saving of real resources used to produce output. The most demonstrable efficiencies are likely to be those associated with lower unit output costs. Efficiency gains that may be relevant include savings related to economies of scale and scope, plant specialization and lower transportation, distribution and overhead costs among various potential areas of efficiencies. When I was Director of Investigation and Research, I outlined in considerably more detail the Bureau's position on efficiency gains in a speech delivered at McGill University. The speech contains the most extensive review of these specific provisions thus far by the Bureau, and anyone interested in this subject can contact the Bureau to obtain a copy of the paper which was released in 1989.

Canadian experience suggests that joint ventures may often expand output and production in the economy, or are useful vehicles for undertaking large capital projects that involve considerable risk. Thus, the 1986 legislation contains a limited exception for combinations that are joint ventures, which have been formed for the purpose of undertaking a specific project or a program of research and development. Several specific criteria must be met. There must be a written agreement which, inter alia, restricts the range of activities of the joint venture and provides for orderly termination of the project upon completion. Restrictions on competition are permitted only to the extent "reasonably required" by the project. Also, the exception is generally limited to high risk ventures. If the project or program would have taken place in the absence of the joint venture, then the exception does not apply. Also, the exception only applies to unincorporated joint ventures.

I cannot leave an overview of the merger provisions of the Competition Act without touching briefly on the prior notification filing requirements of Part 9 of the legislation which came into effect in July 1987. In general terms, the requirement to notify 
is triggered by two thresholds. First, the parties to the transaction, together with their affiliates, must have assets, or annual gross revenues from sales, in excess of $\$ 400$ million. The $\$ 400$ million limit is determined by aggregating all members of the two corporate families involving controlled and controlling affiliates. Only assets in Canada or revenues in, from, or into Canada are to be counted. The second threshold in determining whether a transaction is subject to prenotification is to examine the form of the transaction itself. The prenotification provisions create different rules depending on whether the proposal is an acquisition, amalgamation or combination. Prenotification of acquisitions of assets is required only when the assets to be acquired, or gross revenues in or from Canada generated by those assets, are greater than $\$ 35$ million. Proposals to acquire voting shares must be prenotified where the assets of the acquired corporation would exceed $\$ 35$ million, or the gross revenues from sales generated from the aforementioned assets exceed $\$ 35$ million. Additionally, the acquisition must result in the acquiring party holding voting shares which exceed specific thresholds. In the case of a publicly traded company, this threshold is $\mathbf{2 0}$ percent ( 50 percent if 20 percent or more is already owned) of the votes attached to all of the outstanding voting shares of the acquired corporation. In the case of a nonpublicly traded company, the threshold is 35 percent ( 50 percent if 35 percent is already owned). There are also higher thresholds for amalgamations.

This brief overview of these provisions cannot attempt to cover all the considerations relevant to notification filings; therefore, you should consult the legislation, other speeches available from the Bureau or counsel specializing in this field if you are examining these questions in relation to a specific case. There are specific regulations enacted in relation to the provisions of Part 9 of the Act which should also be examined in determining whether notification is required. Failure to notify under the Act can lead to criminal proceedings brought not only against the corporation but also against individual officers and directors.

Once a determination is made that a notification filing is required, the party or parties proposing the transaction must notify the Director of Investigation and Research (the "Director") of their intentions, supply the information specified in the law and wait from seven to twenty-one days. After the relevant time period has elapsed, the parties are free to proceed with the transaction unless the Competition Tribunal, in response to the Director's application, has issued an interim or final order prohibiting the transaction. In the usual instance, however, if the Director's staff needs more time to complete its analysis and asks for such before the parties close, the parties usually comply in lieu of forcing an application before the Tribunal for an interim injunction.

I would also point out that even though notification is required for mergers that meet the statutory thresholds, a merger that does not meet those thresholds is still subject to review under the legislation. The Act applies to mergers of all sizes in relation to their effect on markets in Canada. Although the focus of the Bureau's attention is ordinarily on larger mergers, there have been cases where relatively small mergers substantially affecting competition in localized markets can give rise to a challenge under the Act. The dairy case in New Brunswick last year and the recent announcement of a challenge by the Director to the western Canadian wire merger are examples of this latter situation.

\section{B. OTHER AMENDMENTS}

While a great deal of the focus of the Canadian legal and business communities has been on the 1986 merger law amendments, the Competition Act also brought into force amendments in a number of other areas. The scope of this paper does not permit 
me to review them all at this time. Briefly, however, I have already mentioned the new abuse of dominant position provisions which replaced the former criminal monopoly provisions. The first case under the abuse provisions was recently heard by the Competition Tribunal in relation to the activities of NutraSweet. The 1986 amendments also strengthened considerably the criminal conspiracy provisions and increased the maximum fine per count to $\$ 10$ million from $\$ 1$ million. There were other amendments to the procedural sections of the legislation, and other substantive amendments which are all discussed in earlier papers available from the Bureau of Competition Policy.

It should be noted that the Director can decide under the legislation to review the same transaction under any of the merger provisions, the abuse provisions or the conspiracy provisions. Normally, mergers and acquisitions done publicly are reviewed only under the merger provisions.

The most significant institutional change resulting from the new Canadian legislation is the creation of the Competition Tribunal under the Competition Tribunal Act. ${ }^{3}$ It is a unique Canadian tribunal modelled in part on the Swedish Market Court and to some extent on the U.K. Restrictive Practices Court. Unlike the U.S. Federal Trade Commission, the new Competition Tribunal has been structured as a purely adjudicative body, without any investigative functions. The Tribunal may consist of up to four judges of the Federal Court - Trial Division and up to eight non-judicial members. It generally sits in panels of three.

The jurisdiction of the Tribunal extends to all of the non-criminal reviewable matters contained in the Competition Act. This includes the new provisions dealing with mergers, abuse of dominant position, specialization agreements and systematic delivered pricing as well as provisions covering restrictive trade practices such as market restriction, refusal to deal, tied selling and exclusive dealing. With one exception, the Director is the only person who may bring applications before the Competition Tribunal; private parties may apply to the Tribunal on notice to the Director for an order to register a specialization agreement. However, any person who may be affected by the outcome of a decision may apply for leave to intervene in any Tribunal proceedings.

For your overall perspective, I should point out that the criminal provisions of the legislation, such as those pertaining to conspiracy, resale price maintenance, bidrigging, discriminatory pricing and other conduct, are also subject to investigation by the Director under the Act. If proceedings are then warranted, the cases are prosecuted by the Attorney General of Canada before the criminal courts.

\section{THE APPROACH TAKEN TO MERGER RESOLUTION}

In implementing the Competition Act, the Bureau adopted what we tended to call a "compliance-oriented" approach. In essence, the approach recognized that most business persons generally make reasonable efforts to ensure compliance with the Act, provided they are given a reasonable opportunity to do so. That is especially so in relation to proposed merger transactions since in Canada, as in other industrialized nations, parties to a proposed merger are very anxious to avoid as much uncertainty as they possibly can. Lengthy time delays and use or threats of the litigious process,

3. S.C. 1986 , c. 26 . 
which may see the prospective effects of a proposed merger analyzed in a public adversarial setting, are not welcomed by parties to a merger. As a result, parties to a merger who are confronted with competition concerns raised by the Bureau are usually willing to see whether they can be resolved in a comparatively expeditious and certain manner. The doors of the Bureau were open therefore to business people who wanted to discuss contemplated transactions. We encouraged parties to make use of the open door policy before they made a public announcement in cases where possible issues under the Act were likely to arise. The doors stayed open throughout the examination and resolution process.

That there were not regularly filed contested merger proceedings before the Competition Tribunal reflected the essential fact that by far the majority of parties to proposed mergers would rather try to resolve the competition concerns through fixing the merger first in conjunction with the closing, or through post-closing resolutions, as opposed to embarking on contested proceedings in an adversarial forum. The same situation exists to the best of my understanding in other industrialized nations.

The Competition Act does not require every merger to be brought by the Director before the Competition Tribunal for a determination of whether or not the merger substantially lessens competition. The Act provides the Director with considerable discretion and a range of alternative choices as to the mode of addressing a particular merger case. For example, in the event that a proposed merger does not raise sufficient grounds upon which a remedial order would be sought within the three year limitation period provided under the legislation, the Director may decide to issue an advance ruling certificate. (The issuance of such a certificate also exempts the transaction from the notification filing requirements of Part 9 of the Act.) Alternatively, the Director can send to the parties a letter under the program of the advisory opinions which may flag certain issues that the Director will be monitoring over the three year period. If the merger does give rise to a likely substantial prevention or lessening of competition, the parties may decide to re-structure the merger in order to "fix it first" so that upon the closing of the transaction, the anti-competitive concerns giving rise to the legal foundation for any application to the Tribunal no longer exist.

Another alternative is for the Director to accept post-closing undertakings to restructure the merger through divestitures sufficient to remove the anti-competitive concerns. Although the legislation does not expressly provide for a codified scheme of undertakings (as was recently enacted in the United Kingdom) precedents for the acceptance of undertakings by the Director go back many years before the 1986 legislation. Alternatively, the Director can negotiate a possible resolution with the parties in the form of a proposed consent order of the Tribunal and bring the appropriate application before the Tribunal in this regard. As well, the Director can, of course, bring contested merger proceedings before the Tribunal. The legislation therefore provides for a range of flexible mechanisms that enable the Bureau to take a pragmatic case by case approach to enforcement of the merger provisions.

In a number of speeches I gave as Director under the Competition Act, I outlined the resolution of cases through the various means that were available to the office. For example, I described the manner in which the proposed acquisition of assets of Interbake Foods by Nabisco Brands was restructured to comply with the Act on a "fix it first" basis. I described other instances such as the acquisition by Canada Safeway of certain assets of Woodward Stores which was not challenged because of undertakings given to divest fourteen supermarkets in the province of Alberta and British Columbia. A number of other mergers which related to companies operating 
or based in western Canada were the subject of merger review under the legislation and are beyond the scope of this paper. For example, the position we took in relation to the failing firm factor in the acquisition of Wardair by PWA Corporation, or the undertakings given by Maclean Hunter in relation to the sale of certain broadcasting facilities in Alberta arising from its acquisition of Selkirk Communications, are discussed in earlier speeches.

Asea Brown Boveri Inc.'s ("ABB") acquisition of various electric power and distribution assets of Westinghouse Canada Inc. was a merger that involved a settlement last year subsequent to the public announcement of an intention to challenge the transaction before the Tribunal. That merger and the merger of the computer reservation systems of Air Canada and Canadian Airlines International (the Gemini case) ${ }^{4}$ which was also initially contested through extensive litigation, were both settled on the basis of precedential consent orders issued in mid-1989.

The $A B B /$ Westinghouse settlement took into account a variety of domestic and foreign competition considerations. I will describe it briefly because of its use of trade policy factors in a competition policy context. A balanced resolution was achieved because the Act allowed for the consideration of the realistic effect of relevant economic factors. They included the impact that both the Free Trade Agreement and ABB's commitment to seek a combination of tariff remission and accelerated tariff reduction would have in reducing barriers to entry and facilitating increased foreign competition. The order in effect says that ABB must obtain tariff reductions for the middle category of transformers on an accelerated basis under the Free Trade Agreement. ABB must also obtain full tariff remissions for at least five years for the largest category of transformers. In the event of failure, divestiture is required. The consent order ensures that domestic market power will be constrained by foreign competition; at the same time it encourages innovative activity in Canada and fosters the attainment of efficiencies that will allow ABB to better compete against foreign competition both domestically and abroad.

I would note that from the filing date of the proposed consent order before the Tribunal to the issuance of the order, the resolution took only seven weeks - including just a half-day of hearings during which counsel responded to comments made by market participants. This was the first case in which a consent order was issued by the Tribunal. Although the original order has been modified by the Tribunal recently on the consent of the parties, its fundamental terms remain the same. I would also note that the U.S. Antitrust Division reached a consent decree resolution, shortly before the Canadian resolution, in relation to the merger's effects in the United States.

\section{OTHER CASE EXAMPLES - RESOURCE INDUSTRIES}

One of the earlier resource industry mergers of a large scale which we examined in the Bureau concerned the acquisition by Fletcher Challenge Limited of British Columbia Forest Products Limited. That transaction was not challenged, in part, because of the availability of alternative foreign sources of supply, including sources in the United States. That case illustrates the importance of the role of foreign competition as a qualitative factor in merger analysis under the legislation. Potential efficiency gains also played a significant role in the Bureau's evaluation of that transaction.

4. Director of Investigation \& Research v. Air Canada et al (1989), 27 C.P.R. (3d) 476. 
Another earlier transaction where the decision not to challenge the merger was based in part on the effects of international market forces was the 1987 acquisition of Dome Petroleum Limited by Amoco Canada Petroleum Company Ltd. Although Amoco and Dome are engaged in four sectors in the oil and gas industry (crude oil, natural gas, natural gas liquids and sulphur) their combined market shares were $r \epsilon$. atively small in all sectors except for natural gas liquids. However, in the latter sector, any competitive concerns were tempered by the ongoing impact of international market forces on competition in relation to natural gas liquid products. Also, there were the mitigating factors of new and alternative sources of natural gas liquid products as well as the jurisdiction of federal and provincial regulatory authorities. The decision was made to monitor the developments in the markets affected by the merger during the three year period provided by the legislation.

Similarly, the 1988 acquisition by Nova Corporation of its interest in Polysor Energy \& Chemical Corporation was not challenged under the Act, but was placed on a monitoring track for the statutory three year period. The one common activity of the two companies involved the production of ethylene. As the news release which accompanied the decision indicated: ${ }^{5}$

Based on the detailed assessment of the acquisition, the Director's present expectation is that the competitive effects of the transaction are likely to be affected by a number of important considerations. For example, because of the existence of long-term contractual agreements the merger is not likely to affect competition in ethylene for many years to come. Moreover, the Director intends to closely monitor the status of these contracts, including any early renegotiation of the contracts. Other factors to be monitored include: possible changes in Alberta Government policy regarding the development of the province's petrochemical industry, including the restrictions on shipments of ethylene from Alberta; changes in the economics of transporting ethylene on the Cochin Pipeline; the possibility for new entry or the expansion of existing ethylene production facilities in Ontario or in Alberta; and the degree to which Nova exercises market power as the result of the acquisition with respect to its customers or competitors.

Given the number of variables that exist, the Director concluded that, with the benefit of additional information obtained through the monitoring process, he will be in a better position to assess the effects and likely future effects on competition resulting from this acquisition at a later stage in the three-year period.

The decision also noted that petrochemical derivative markets are North American in scope and are very competitive; moreover, the implementation of the Canada-U.S. Free Trade Agreement is expected to make these markets even more competitive, and its impact would also be monitored. Thus, once again the role of existing and potential foreign competition in relation to the resource sector was an important consideration in the analysis of a merger.

As I mentioned above, a good number of transactions in the oil and gas industry have been examined since 1986 by the Bureau of Competition Policy. Although the financial magnitude of some of those transactions were large in comparison to most other industries, the upstream sector has remained relatively unconcentrated, and Canadian oil and gas prices are significantly influenced in that sector by international market forces. We have also been facing a period of excess supply which likely would constrain any real market power to affect prices in that sector. Thus, transactions in relation to that sector were not the subject of a contested application before the Competition Tribunal when I was Director, and to the best of my understanding, my successor has not challenged any since October 1989. For your interest, some of the larger transactions in this industry which were publicly reported in the last two years' Annual Reports of the Director of Investigation and Research include, for example: 
- British Gas PLC's acquisition of Bow Valley Industries Ltd., where an advance ruling certificate was issued;

- Esso Resources Canada Limited's acquisition of Sulpetro Limited/Sulbath Exploration Ltd., where an advance ruling was issued;

- Gulf Canada Resources Ltd.'s acquisition of Asamera Inc., where the file was closed;

- Noranda Inc. 's acquisition of Norcen Energy Resources Limited and North Canadian Oil, where the files were closed;

- T.C.P.L. Energy Limited's acquisition of Encor Energy Corporation Inc., where the file was closed;

- Bow Valley Industries Ltd.'s acquisition of certain assets of Ocelot Industries Ltd. and of Bonanza Oil \& Gas Ltd., where an advance ruling certificate was issued;

- Husky Oil Limited's acquisition of Canterra Energy Ltd., where an advance ruling certificate was issued;

- Inland Natural Gas Co. Ltd.'s acquisition of 4280 B.C. Ltd., where the file was closed; and

- Pan Canadian Petroleum Ltd.'s acquisition of certain assets of Canadian Occidental Petroleum Limited, where an advance ruling certificate was issued.

\section{RECENT DEVELOPMENTS}

I propose now to move away from the discussion of primarily mergers and to briefly highlight some of the more significant developments over the last six months or so in relation to the administration of the Competition Act.

\section{A. THE CHRYSLER CANADA CASE}

Last October, the Competition Tribunal handed down its first decision under section 75 of the Competition Act. That section is known as the "refusal to deal" section. The section provides that where, on application by the Director, the Tribunal finds that a person is substantially affected in his business due to his inability to obtain adequate supplies of a product anywhere in a market on usual trade terms because of insufficient competition among suppliers of the product, and the person is willing and able to meet the usual trade terms of the supplier and the product is in ample supply, then the Tribunal may order that one or more suppliers of the product in the market accept the person as a customer within a specified time on usual trade terms.

In this case, the Tribunal found that the section's criteria were met and, as a result, ordered Chrysler Canada Ltd. to accept one Richard Brunet as a customer for the supply of Chrysler automotive parts on trade terms usual and customary to its former relationship with $\mathrm{Mr}$. Brunet. The case involved the export of automative parts by Mr. Brunet to countries outside of North America. Mr. Brunet had been encouraged by Chrysler in its prior association with him to expand the sale of Chrysler automative parts in the export market, but for various reasons in more recent years, Chrysler had changed its policy of supply to Mr. Brunet.

6. Canada (Director of Investigation \& Research) v. Chrysler Canada Lid. (1989), 27 C.P.R. (3d) 1 (Competition Bureau). 
The Tribunal's decision is of precedential effect in a number of ways. It is the first time that an order of this nature has been given under that section of the Act. As well, the case involved considerable analysis by the Tribunal of the definition of "product", with the Tribunal concluding that the relevant product in that case consisted of Chrysler auto parts, and that the relevant market was Canada, with the U.S. and Canada being separate markets. The Tribunal focused on the existence of separate price lists in the U.S. and Canada, and the fact that they are intended to respond to different market conditions in the two countries, as being strongly supportive of the existence of separate markets. The Tribunal also agreed that the term "substantial" should be given its ordinary meaning. The Tribunal said that terms such as "important" are acceptable synonyms. Thus, although Chrysler was trying to institute its own policy to control the destination of its automotive parts, this section of the legislation overrode that, and Chrysler is now subject to the requirement to comply with section 75 of the legislation in relation to Mr. Brunet. I should add that Chrysler has filed an appeal of the Tribunal's decision.

I should note that my successor has recently brought contempt proceedings against Chrysler for allegedly failing to comply with the Tribunal's order. Chrysler has denied the alleged contempt and has also challenged the Tribunal's jurisdiction to hear the contempt proceedings. So both the substance of the original order and the contempt issue are now before the Federal Court of Appeal. ${ }^{7}$

The Director has recently also brought a similar case under the refusal to deal section against Xerox Canada. The hearing before the Tribunal has not yet commenced in that case but is expected to in the near future. ${ }^{8}$

\section{B. THE IMPERIAL OIL/TEXACO CANADA MERGER}

I do not intend to run through the Imperial Oil/Texaco merger proceedings in any detail since an entire paper could easily be devoted to that case. I also do not propose at this time to discuss the substance of the decision in that case. That proposed merger was announced in January 1989 and, at the end of June 1989, we filed an application before the Competition Tribunal for a proposed consent order. In addition to the lengthy documents that were filed, which included various affidavits of leading experts in support of the proposed order and a detailed competitive impact statement, the Tribunal published a notice of the proposed consent order and there was opportunity for comments from any interested persons. Comments were received and the Competition Bureau filed responses. There was then a hearing regarding applications for intervention status before the Tribunal. The Bureau submitted that the intervenors ought to be limited to making oral or written argument but the Tribunal decided to

7. On July 10,1990, the Federal Court of Appeal decided that the Competition Tribunal does not have the jurisdiction to hear contempt proceedings in relation to an alleged failure to comply with an order of the tribunal: Chrysler Canada Lid. v. Competition Tribunal et al, (10 July 1990), Ottawa A-135-90 (F.C.A.D.).

8. Xerox Canada has not only denied the Director's assertions but has brought an application for a declaration that the proceedings should be declared void on the basis that the Tribunal's powers contravene the Canadian Charter of Rights and Freedoms, on the grounds asserted by the Quebec Superior Court recently in the Couture case, infra, note 16. Xerox Canada has also raised the constitutional issue of whether the Tribunal has jurisdiction to address a case under $\mathbf{s}$. 75 of the Competition Act (refusal to deal) on the grounds that the section infringes provincial constitutional authority over property and civil rights. 
give certain intervenors the right to lead evidence, cross-examine witnesses and make argument in the same fashion as they would in an adversarial proceeding.

I think it is fair to say, and indeed the Tribunal subsequently recognized, that the consent order proceedings were significantly delayed because of the request of counsel for the intervenors to allow them sufficient time to prepare for the leading of evidence and the cross-examination of experts and, of course, the time was then taken in the hearing for that to occur.

The Tribunal decided in its provisional decision handed down in mid-November 1989 (after I had stepped down as Director) that it would not grant the proposed consent order; however, the Tribunal gave the parties an opportunity to develop revised provisions to meet the Tribunal's concerns. A revised proposed consent order was subsequently filed with the Tribunal and once again, in lengthy reasons delivered in late January 1990, the Tribunal declined to grant the proposed consent order. The order was, however, eventually granted in early February 1990, without additional reasons after further modification to certain terms of the proposed order. I do not propose to comment on the substantive aspects of the proposed and final orders.

As a result of these particular consent order proceedings, one can fairly state that a number of questions have been raised regarding the future utility of consent order proceedings under the Competition Act. In its reasons, the Tribunal appears to have established a significantly higher evidentiary burden on the applicants for a proposed consent order in certain circumstances and, even more importantly, appears to be giving intervenors considerable latitude to displace a proposed consent order if it can be shown at the hearing that particular objectives of the order may not be met. In this case, there were fifteen intervenors that appeared before the Tribunal either individually or by counsel. The Tribunal indicated that, through participation of the intervenors, the Tribunal is able to test a proposed consent order and that the rationale for giving intervenors a more extensive role in any such consent order proceedings is, according to the Tribunal's current view, as strong if not stronger than in contested proceedings.

These developments have generated considerable discussion in the Canadian legal and business communities about the procedures and burden placed on applicants for a consent order. At the same time, it is apparent that through this more involved process, the Tribunal will likely attain a more detailed appreciation of the prospective operational nature of a proposed consent order. However, a question that is currently being discussed is what are the consequences of this type of potentially more litigious proceeding in relation to the continued and realistic use of the consent order vehicle as a remedy for problematic merger cases. As with so many other questions of competition policy, it is an issue that inherently necessitates a balancing of competing objectives.

As some of you may appreciate, the approach that was taken recently by the Tribunal panel in the Imperial Oil case is considerably different from the approach taken by the courts in the United States to proposed consent decrees under the Tunney Act, ${ }^{9}$ especially in relation to the role of intervenors in the process. The position we had advocated before the Tribunal in relation to the role to be given to intervenors on a consent order application was not significantly different from the procedures that have been utilized effectively in the United States for many years under their Tunney 
Act consent order process. In those cases, interested persons may obtain amicus standing which allows them to file and present argument, as opposed to having the same status as parties. The Tribunal's approach also differs from that generally taken by superior courts in Canada to consent prohibition orders issued under the criminal provisions of the Competition Act.

The Tribunal itself noted in the earlier Gemini merger case ${ }^{10}$ that Parliament has sent a clear message in the Competition Act that the Tribunal should not take a detailed role in the crafting of consent orders. It therefore remains to be seen whether the Tribunal's approach to the Imperial Oil case resulted from the unique and very broad public interest and public impact of that case, or whether it signals a more activist posture on the part of the Tribunal in future consent order proceedings. The legislation is still evolving and, in my view, the approach that the Tribunal takes to the next one or two consent order proceedings will be determinative in answering the question of whether the consent order provisions of the legislation will see constructive future use made of them on a regular basis. In the interim, some competition law counsel have indicated they likely will try to have problematic merger cases resolved with the Director as opposed to the uncertainty of consent proceedings before the Tribunal. However, the Director simply cannot resolve all mergers, so it is only a matter of time before another proposed consent order proceeds before the Tribunal.

\section{THE THOMSON NEWSPAPERS CASE"}

At the end of March 1990, the Supreme Court of Canada handed down an important procedural decision which addressed the question of whether pre-charge compulsory testimony under the predecessor legislation contravened the Canadian Charter of Rights and Freedoms. ${ }^{12}$ While the section was specifically amended in the 1986 Competition Act, the Supreme Court's Charter analysis also has bearing on the comparable provision in the 1986 legislation.

The Ontario Court of Appeal had held in this case ${ }^{13}$ that section 17 of the Combines Investigation Act did not violate the Charter. Section 17 required persons under investigation to answer questions under oath and to produce documents when compelled to do so in a hearing conducted in the context of an inquiry under that legislation. The Supreme Court of Canada sat in a panel of only five members in hearing and deciding this case. The members of the Court split in their decisions on a three to two basis in favour of the constitutional validity of the legislation in relation to the unreasonable seizure section of the Charter. However, in relation to the fundamental justice section of the Charter, two members of the Supreme Court of Canada decided that section 17 does not contravene that section of the Charter while two other members of the Supreme Court of Canada decided that it does. The fifth member of the Supreme Court of Canada panel held that the appellants had challenged the wrong section of the legislation and, as a result, in his view, the Court ought not to pron-

10. Supra, note 5 .

11. Thomson Newspapers Ld. v. Director of Investigation and Research. Combines Investigation Act et al (1990), 106 N.R. 161 (S.C.C.).

12. Canadian Charter of Rights and Freedoms, Part I of the Constitution Act, 1982, being Schedule B of the Canada Act 1982 (U.K.), 1982, c. 11 [hereinafter Charter].

13. Thomson Newspapers Ltd. v. Director of Investigation and Research, Combines Investigation Act et al (1986), 34 D.L.R. (4th) 413 (Ont. C.A.). 
ounce on the fundamental justice issue without a challenge of the appropriate section of both that legislation and the Canada Evidence Act. ${ }^{14}$

The result of the split in the Supreme Court's decision is that the decision of the Ontario Court of Appeal stands and the section of the legislation has not been struck down. However, the Supreme Court has not affirmed the validity of the compulsory testimony section of the legislation by any specific majority decision addressed to that point in relation to the fundamental justice provision of the Charter. Moreover, in an even more recent decision of the Supreme Court of Canada in the Starr inquiry, ${ }^{15}$ the Court, sitting in a larger panel, struck down the authority for compulsory testimony in a provincial public inquiry which was examining conduct in a context similar to a federal criminal investigation. While the issues are not the same as those in the Thomson case, it is clear that on reading the two cases together, the question of compulsory pre-charge testimony in the context of a Competition Act inquiry is still not finally decided. Thus, in future proceedings under section 11 of the Competition $A c t$, where an order is made requiring a person to attend and be examined on oath, there is a good reason to believe that those proceedings will once again become embroiled in court challenges.

\section{THE COUTURE CASE 16}

In early April 1990, the Quebec Superior Court handed down a decision in this case which declared that the Competition Tribunal and three sections in the merger provisions of the Competition Act are unconstitutional. The decision appears to be primarily based on the fact that the Tribunal consists of both judicial and non-judicial members with the Court concluding that the non-judicial members are not sufficiently independent of the Government to allow the Tribunal to exercise functions similar to a court. The decision ought not to affect the constitutionality and operation of the legislation in provinces outside of Quebec. The Government has now announced that it will appeal the decision. As a result, I do not propose to comment further on the substance of the issues in that case.

I would note in this regard that in the NutraSweet case, ${ }^{17}$ defence counsel have recently indicated they will be raising the Couture decision in relation to the constitutionality of the Tribunal. That issue is expected to be argued before the Tribunal in the very near future.

I would also note that in 1989, the Supreme Court of Canada finally held in the City Leasing v. General Motors case,$^{18}$ that the predecessor legislation, the Combines Investigation Act, is constitutionally valid under the federal trade and commerce power as well as under the federal criminal law power. That decision by the Supreme Court was one that specifically affirmed the civil damages remedy in the legislation. At the same time, the decision laid to rest any debate about the constitutional validity of the

14. R.S.C. 1985 , c. C-5.

15. Starr et al v. Houlden (5 April 1990) Ottawa Doc. No. 2177 (S.C.C.).

16. Alex Couture Inc. et al v. Attorney General of Canada: Competition Tribunal et al (1990), 30 C.P.R. (3d) 486 (Quebec S.C.).

17. The Director of Investigation and Research v. The NutraSweet Company, Competition Tribunal, No. CT-89/2.

18. City Leasing v. General Motors (1989), I S.C.R. 641 (S.C.C.) affirming (1986), 9 C.P.R. (3d) 134 (Ont. C.A.). 
new merger provisions of the Competition Act because the Court held that competition legislation can be enacted by Parliament under the trade and commerce power. However, the specific Charter issue addressed by the Quebec Superior Court in the Couture case was not considered by the Supreme Court of Canada in its 1989 decision.

\section{E. THE STEINBERG'S CASE ${ }^{19}$}

Another recent Quebec Superior Court decision concerns the issue of whether private persons can challenge a merger or whether only the Director under the Competition Act can do so before the Competition Tribunal. The issue is not entirely dissimilar from the one the United States Supreme Court decided last month in favour of private persons and State Governments having the right under the Clayton Act ${ }^{20}$ to seek an order of divestiture even after a merger has closed and even though the parties may have complied with a consent order that resolved the concerns of the federal antitrust authorities. ${ }^{21}$ However, thus far in Canada, based on the Quebec Court's decision in the Steinberg's union case, only the Director can challenge a merger on the basis that it substantially lessens competition under the Act; private parties do not have recourse to stop a merger or seek divestiture under the provisions of the Canadian legislation. Private parties will therefore have to bring their concerns to the Director's attention and hope to persuade the Director to either commence proceedings before the Tribunal or otherwise address their concerns in the resolution of the merger under the Act.

\section{F. THE DIRECTOR'S PRIORITIES}

My successor, Howard Wetston, was the Senior Deputy Director in charge of the Mergers Branch of the Bureau when I was Director. He has recently outlined publicly the priorities he is setting for the Bureau of Competition Policy. While those of you who are interested can certainly obtain a copy of Mr. Wetston's speech from the Bureau, I would note that he has set the following objectives. First, he proposes to issue two additional information bulletins which will give the business community guidance on the manner in which the Bureau is interpreting and applying the discriminatory pricing provisions and the predatory pricing provisions of the Competition Act. Secondly, as a result of the experience gained in the Bureau since the 1986 amendments, Mr. Wetston is giving high priority to the production of a published document on merger guidelines for the use of the business and legal communities. That document is expected to address such concepts as market definition, foreign competition, barriers to entry, the application of the Act to failing firms and the key issue of trade-offs between efficiency gains and reduced competition. These guidelines are expected to provide more specific analytical criteria than the many speeches and bulletins we issued from 1986 to 1989 . Third, Mr. Wetston will be examining ways to streamline the consent order process in light of the Imperial Oil/Texaco consent order proceedings. Fourth, he has indicated his view of an increased role for

19. Travailleurs et Travailleuses Unis de l'Alimentation et du Commerce, Local 500 et al v. Corporation d'Acquistion Socowon-Caisse Inc. (2 March 1990), No. 500-05-014157-893 (Que. S.C.).

20. Antitrust Procedures and Penalties Act, 15 U.S.C.A. 12-27.

21. California v. American Stores Co. (30 April, 1990), No. 89-258 (U.S. Sup. Ct.). 
the Bureau and market forces in relation to regulated industries. Fifth, in relation to the Canada-U.S. Free Trade Agreement, Mr. Wetston has stated that he wants to strengthen the links between the Canadian and United States antitrust authorities. In that regard, he indicated that they have already set up working groups to tackle problems of common concern. Finally, Mr. Wetston has indicated that the Bureau will take a vigorous line on criminal conduct such as price-fixing and bid-rigging and that it will be fully prepared to see charges brought against individuals in order to deter such illegal economic activities.

As an aside, I would note that from 1986 to 1989 we did establish a number of precedents for criminal fines including a total of $\$ 2$ million in the business forms bidrigging convictions. In addition, Shell Canada's fine upon its 1989 conviction for resale price maintenance in Manitoba was recently increased on appeal from $\$ 100,000$ to $\$ 200,000 .{ }^{22}$ As well, just last month charges were laid in the Quebec pharmacists proceedings against not only a number of corporations but also against a number of individuals; they have now brought a court challenge against the constitutionality of the conspiracy section on the basis of arguments in relation to certain provisions of the Charter. ${ }^{23}$

Although Mr. Wetston has indicated that he intends to increase the stakes on certain criminal cases, he has not indicated any shift in the compliance-oriented approach to the merger review process under the legislation. In other words, the fundamental aspects of maintaining an open-door policy aimed toward a realistic administration of those very important provisions is likely to continue under Mr. Wetston. He is a knowledgeable and pragmatic individual whom I believe will apply the law in a manner that Parliament intended. That is not always an easy task given that those who administer merger legislation can often be equated to those who walk a tight-rope, but it is a task that can and must be performed in a careful and balanced manner.

\section{G. PRE-MERGER NEGOTIATIONS}

A few months ago the United States antitrust authorities cautioned that pre-merger discussions and related information exchanges could in some circumstances give rise to questions of whether the parties had gone beyond the bounds of propriety and engaged in a criminal conspiracy, in situations where the discussions subsequently did not result in a merger taking place. This has served to heighten the attention paid to those negotiations by U.S. antitrust counsel; it may also be causing the Canadian Bureau to pay more attention concurrently. While the U.S. law as to what may constitute a Sherman $A c t^{24}$ conspiracy is stricter than the elements required to show a Competition Act conspiracy, nonetheless, pre-merger discussions between two major competitors in a Canadian market should follow two fundamental guidelines to protect against any basis for a conspiracy inquiry subsequently arising from pre-merger discussions which did not lead to completion of the merger.

22. R. v. Shell Canada Products Lid. (1990), 29 C.P.R. 32 (Man. C.A.).

23. R. v. Nova Scotia Pharmaceutical Society (5 September 1990), Halifax No. 11486, that the conspiracy section of the Competition $A c t$ is unconstitutional on the basis that it contravenes the Charter.

24. Antitrust Procedures and Penalties Act, 15 U.S.C.A. $\$ 1-7$. 
First, there should be a confidentiality agreement in place which, among other things, makes it clear that the sole purpose of the discussions and material exchanged is to evaluate the merits of the possible merger, and that the information will not be used for any other commercial or operational purpose. There are other provisions that should also be considered for inclusion in a confidentiality agreement such as recording information exchanged and providing for its return if the merger does not proceed, and limiting circulation of the information exchanged, among other possible terms.

Second, the information exchanged through documents or discussions should be limited to that which is necessary to evaluate and consummate the merger, and generally should not include such sensitive areas as present and future pricing, plans in relation to particular customers or suppliers, detailed current costs, and confidential strategic business or marketing plans, among other possible topics. Each situation should be examined according to the competitively sensitive areas of that industry. As well, such discussions should proceed generally on the basis of analyzing where the two parties plan to be "if the merger proceeds". If you are in doubt in this delicate area, you should consult competition law counsel.

\section{IMPLICATIONS OF THE FREE TRADE AGREEMENT}

In the final part of my remarks today I want to comment on some of the implications of the Canada-U.S. Free Trade Agreement for proceedings under the Competition Act.

First of all, I think there is every likelihood that we will see a smooth adaptation to the challenges that lie ahead in this regard. A considerable degree of cooperation already exists in competition matters between Canada and the United States. Well before the Free Trade Agreement came into effect, Canada and the United States set up machinery for regular consultation on the application of our national antitrust laws. As far back as 1959, both countries signed a Memorandum of Understanding on the subject, which was updated in 1984. From my own experience as Director, I can tell you that we had an excellent working relationship with the Antitrust Division of the Department of Justice and with the Federal Trade Commission. Our degree of contact increased considerably over the three and one-half years that I was Director due in large part to the unprecedented merger wave and the considerable amount of trans-border activity in that respect.

In the speech that I gave in 1988 to the Antitrust Section of the American Bar Association, I discussed the increasing convergence between Canadian and U.S. competition policies over the past decade. To some extent, that has occurred because U.S. experience was considered in framing the Competition Act. The converging trend is most apparent in the area of mergers. Both countries assess mergers on the basis of their effect on competition. Both go beyond simple quantitative analysis in their assessment of the pros and cons of a merger, and a number of similar factors are considered in the exercise of the law enforcement function in both countries. While there are differences in the enforcement of our respective merger laws, those differences are not likely, in my view, to lead to trade distortions. I also think that differences in procedures and in other areas of our competition laws (such as price discrimination and resale price maintenance), while possibly significant in relation to specific business activities, are unlikely to generate sizeable trade distortions. 
Having said that, I think that there are some areas that will require attention over the next few years. First, it may be argued that providing an exemption under competition laws for export activities within the free trade area may be at odds with the purposes of the Free Trade Agreement. By allowing domestic firms to form a cartel for export purposes, different treatment is endorsed between activities pertaining to the domestic market and those directed at foreign markets. There is, therefore, a question that warrants further study as to the extent to which export exemption provisions should remain in the law of each jurisdiction in relation to the free trade area.

Another question that has been raised is whether market definition ought to be reexamined because of the lowering of, or reduction of, market barriers under the Free Trade Agreement. In my view, there is no immediate need for a significantly different approach under the Canadian law than the one already taken to the assessment of the relevant market. At the same time, because there are qualitative factors in section 93 of the Competition Act which specifically deal with barriers to entry and foreign competition, it is likely that those factors will be given significantly more weight in future merger assessments. In other words, the relevant geographic market is likely to remain as Canada in its broadest sense for purposes of an assessment under the Competition Act since the Act addresses the effect of a transaction in Canada. However, as the barriers decrease, the foreign competition factor will become increasingly more important in the overall assessment of whether a merger is likely to give rise to a substantial lessening of competition in Canada. Clearly, the Free Trade Agreement will affect different industries in a different fashion depending on the significance of tariffs as barriers to foreign competition in those industries.

It is also likely that we will be seeing, at least in Canada, greater use of the efficiency provisions of the Competition Act in relation to the effects of the Free Trade Agreement. In that regard, gains in efficiency which are likely to give rise to net trade benefits are given added weight in the balancing process under the Act. It is likely, therefore, that counsel will be placing increasing reliance on those specific provisions. In fact, as I indicated in speeches given last year, those kinds of submissions were already starting to take place. I also outlined in speeches last year examples of cases where efficiency gains have played a role under the legislation, and I would anticipate that role will increase as we proceed through the 1990s. In this regard, a number of economists whom I have encountered in Canada and in the United States over the past few years have held the view that industries in Canada can be expected to embark on an even greater rationalization process than those in the United States to achieve economies of scale in order to compete effectively as trade barriers are lowered and markets become more globalized. Thus, we will likely see some pretty active consideration of these particular efficiency provisions over the next few years.

Another area which will likely see increased use under the Competition Act is the set of provisions governing specialization agreements. Although no such application has yet gone forward to the Competition Tribunal, I think that as certain industries begin to specialize and rationalize in core business areas, it is only a matter of time before we see increased use made of those provisions as well. Once again, the balancing of efficiency gains against competitive effects comes into play in relation to those provisions in the same manner as it does in the merger provisions. Specialization in core business areas is expected to become a more common phenomenon as we proceed through the $1990 \mathrm{~s}$. 
I think we can also expect to see the antitrust authorities make even greater use of the Canada-U.S. Memorandum of Understanding than that which has occurred over the last few years. As businesses engage in more and more trans-border activities, the antitrust authorities in Canada and the United States are likely to have even more contact both on a formal and informal basis. In fact, when the Assistant Attorney General in charge of the Antitrust Division, Jim Rill, was speaking at the Canadian Centennial Conference for competition legislation last October, he indicated that he wanted to pursue even more regularized meetings with the Canadian Bureau, and he received a very favourable response to his initiative at that time.

One can also foresee that as a result of a decreasing role played by Investment Canada in relation to the review of U.S. acquisitions of Canadian businesses, the Bureau of Competition Policy will likely be even more in the foreground than before. As I am sure most of you appreciate, Investment Canada reviews foreign acquisitions of Canadian businesses above certain levels. Those thresholds are being raised for U.S. acquirors and by 1992, except for cultural industries and the oil, gas and uranium sectors, the threshold for review of direct U.S. acquisitions will rise to $\$ 150$ million. For indirect U.S. acquisition the threshold will be lifted completely by 1992 . Those changes are specifically a result of the Free Trade Agreement and they will not affect Investment Canada's review of investment from other countries.

It should also be appreciated that Investment Canada, which is concerned with broader net benefits to Canada, is not bound by the Competition Bureau's opinion on the competition factor, which is only one factor in the Investment Canada assessment. At the same time, the Competition Bureau is not bound by an Investment Canada decision. The merger test outlined in section 92 of the Competition Act applies even if the acquisition has been approved by Investment Canada. The Competition Act applies to mergers of all sizes and in all sectors of the Canadian economy. Thus, the Competition Act and the Bureau of Competition Policy are likely to play an increasingly significant role in relation to U.S. acquisitions as the 1990 s unfold.

Finally, it should also be appreciated that one stated goal of the Free Trade Agreement is the improvement of the current system governing trans-border pricing practices. The Free Trade Agreement establishes a Working Group under Chapter 19 which will look at the possible development of a substitute regime to replace existing trade remedy laws within the next five to seven years. The goal of any new regime would be to obviate the need for border remedies such as those now sanctioned by the GATT anti-dumping and subsidies codes, for example, by developing new rules on subsidy practices and relying on domestic competition law. In this context, the use of domestic competition laws such as discriminatory pricing provisions and predatory pricing provisions to replace anti-dumping laws is expected to be given specific consideration. I would note in this regard that members of the European Economic Community do not apply independent national anti-dumping laws against other member states.

For those who may be interested in this particular subject, I and other panellists addressed the various issues involved in relation to the substitution of competition laws for anti-dumping laws at a conference held at Case Western University School of Law in April 1987, and my paper is available from the Bureau of Competition Policy. It will be quite interesting to see whether the Working Group does conclude with a recommendation that anti-dumping laws ought to be replaced by the discriminatory pricing and predatory pricing provisions of competition law because, if they do, a good deal of further study will have to be conducted in relation to what kind of antitrust regime ought to specifically be put in place in that respect. 


\section{CONCLUSION}

Although somewhat lengthy, I hope that the overview I have provided today will prove to be of some assistance to you in the course of your professional practices. We have a relatively new statute in Canada that many regard as being on the forefront of antitrust laws in the industrialized world. At the same time, as with any other new legislative regime, there is an evolution process that naturally takes place over a period of time. For counsel in the oil and gas industry, it is important to be aware of the potential applicability of the Competition Act to various aspects of your clients' business activities and proposed transactions. The last thing any of us would like to see is an inquiry or subsequent proceeding that could readily have been averted if knowledgeable advice had been provided to the client at an early stage in its planning process. 